\title{
Trabalho cooperativo no MST e ensino fundamental rural: desafios à educação básica*
}

\author{
Marlene Ribeiro \\ Faculdade de Educação, Universidade Federal do Rio Grande do Sul
}

\section{Introdução}

O trabalho cooperativo, que toma diferentes designações, é hoje um fenômeno que assume importância econômica e visibilidade social cada vez maiores, atraindo a atenção dos pesquisadores das diferentes áreas do conhecimento, entre elas a educação. Em todas as épocas, a educação tem estado diretamente ar-

* O presente artigo resulta do projeto de pesquisa Pedagogias de esperança nos Movimentos Sociais Populares: perspectivas para o trabalho, a política e a educação projetadas pelo MST. Esse projeto foi posteriormente desdobrado em dois subprojetos: $A$ viabilidade dos assentamentos de reforma agrária como uma resposta à questão social do desemprego: uma avaliação do trabalho técnico-pedagógico do Lumiar/RS, desenvolvido em parceria com INCRA, COCEARGS, CAPA, UFRGS e apoiado pela FINATEC, concluído em fev./2000; e Experiências cooperativas no campo e na cidade: subsidiando políticas sociais alternativas em trabalho, educação e lazer, pesquisa interdisciplinar e interinstitucional em fase de conclusão, envolvendo as Universidades Federais do Rio Grande do Sul e de Pelotas e a Católica de Pelotas, e apoiada pela FAPERGS. ticulada às formas de organização das atividades de sustentação da estrutura social, sejam elas produtivas, comerciais, políticas, culturais ou religiosas. A educação moderna, vinculada ao sistema capitalista de produção, institui-se como escola, separando-se do trabalho porém submetida as suas determinações (Ribeiro, 1997). Esta escola formadora de um indivíduo capaz de competir por uma vaga no mercado de trabalho, que tinha por princípios tanto a disciplina do corpo (Foucault, 1984), imposta pelo tempo da máquina (Thompson, 1984), quanto a subordinação às condições determinadas pelas relações sociais de exploração do trabalho (Enguita, 1989), parece ter esvaziadas as suas funções de preparar para o trabalho, integrar a sociedade através da habilitação para um emprego e contribuir, como aparelho de Estado, para o controle ideológico. ${ }^{1}$

${ }^{1}$ Atravessada pelas contradições próprias das classes sociais que lhe dão vida e conteúdo, a escola nunca se conformou ao modelo, aproximando-se, às vezes mais e às vezes menos, do limite entre a conservação e a ruptura. Por ora, no entanto, o meu interesse é mostrar as possibilidades de ruptura daquele modelo. 
A substituição do modelo taylorista-fordista de produção pelo paradigma da acumulação flexível baseia-se na aplicação de novas tecnologias aos processos produtivos que acabam por eliminar milhões de postos de trabalho, gerando o desemprego tecnológico (Singer, 1998; Secco, 1998). Associada a essas transformações, o que alguns autores explicam como crise fiscal do Estado (Bobbio e outros, 1995; Todeschini e Magalhães, 1999) e outros como neoliberalismo ou retirada do papel do Estado enquanto financiador de políticas de caráter social (Oliveira, 1998; Fiori, 1998) gera o desemprego estrutural.

O desemprego, um fenômeno peculiar ao capitalismo, intensifica-se a partir dos anos de 1970 (Rifkin, 1995), dando origem a uma nova questão social (Castel, 1998). Ampliando a crise, o reaquecimento das economias dos países desenvolvidos, retomada no final dos anos de 1980 e início dos anos de 1990, não foi capaz de reverter a tendência crescente do desemprego (Anderson, 1995), colocando em xeque, entre outras instituições, o modelo burguês de escola pública gestado na modernidade. Há autores, como os que têm seus textos organizados por Aued (1999), que vêm refletindo sobre educação para o (des)emprego. Paro (1999), em seu texto, parece recomendar "Parem de preparar para o trabalho!!!” Gentili (1998) já manifestara que, no estágio atual do capitalismo, aquela escola que formava para o emprego (o que explica a expansão dos sistemas educacionais no século XX) já não corresponde às necessidades de um mercado de trabalho que elimina postos de trabalho e não os substitui em número equivalente. Em conseqüência, a formação escolar estaria orientada para o desemprego. Entretanto, diz ainda o mesmo autor, se aquela escola era legitimada pela promessa integradora, há um longo caminho entre o discurso da "integração" e a realidade: manteve-se a pobreza, a desigualdade e o exército industrial de reserva, regulador dos salários.

Em confronto com os valores da competição, disciplina e submissão, próprios da escola moderna, o trabalho cooperativo, como o próprio nome indica, baseia-se na cooperação, na solidariedade e na autonomia. Visualizado, então, esse confronto de valores, cons- truo questões que delineiam alguns desafios colocados à escola básica, tema deste trabalho: Qual o futuro da escola básica, especialmente pública, diante da emergência de novas formas de organização das relações de trabalho baseadas na cooperação, na solidariedade e na autonomia? Em se tratando do trabalho cooperativo, que questões o mesmo coloca para a escola básica?

Aproximando-me um pouco mais dos sujeitos/ objeto da pesquisa - os agricultores familiares assentados, que desenvolvem um trabalho cooperativo, e os professores do ensino fundamental de duas escolas rurais, nas quais estudam os filhos dos agricultores -, delimito o problema em torno de uma questão: Que desafios o trabalho cooperativo, desenvolvido por agricultores familiares dos assentamentos de Reforma Agrária do Movimento dos Trabalhadores Sem-Terra (MST/RS), coloca para o ensino fundamental rural e, além deste, para uma escola básica que esteja em consonância com os interesses desses agricultores?

Portanto, o objetivo deste trabalho é visualizar alguns desafios que o trabalho cooperativo desenvolvido pelos agricultores assentados está apontando para a educação básica e, em particular, para o ensino fundamental rural. A metodologia articula uma revisão bibliográfica sobre o tema economia solidária com a pesquisa-ação, feita junto a assentamentos de Reforma Agrária do MST/RS, focalizando a relação entre o trabalho cooperativo e a educação escolar.

Farei, de início, uma caracterização do trabalho cooperativo, sob a ótica da economia solidária, baseada, principalmente, em estudos de Singer (1997, 1998, 1999a, 1999b, 2000), Rech (1995), Schneider (1999), Limberger (1996), Gaiger (1999), Arruda (1996), Gohn (1997,1998, 2000), Tiriba (1998), Gadotti e Gutiérrez (1999) e Razeto (1999), tendo, como contraponto, a discussão sobre cooperativas que aparece nas obras de Marx (1982), Luxemburgo (1986), Kautsky (1972) e Lenine (1980). Num segundo momento, abordarei, na perspectiva de alguns desses autores, os limites que a escolarização ou a sua ausência impõe ao trabalho cooperativo. Passarei, após, a focalizar o conflito entre o trabalho cooperativo dos agri- 
cultores assentados e a formação escolar de seus filhos, baseando-me, de um lado, em estudos sobre educação rural, efetuados por Calazans (1993), Gritti (2000), Ribeiro (2000b), Nunes (1998) e sobre a proposta de educação do MST, efetuados por Caldart (1997, 2000) e Camini (1998). De outro, no reconhecimento, por parte dos próprios assentados, de que necessitam da escola mas que aquela que lá está lhes é contrária às formas como vêm tentando organizar seu trabalho, e suas vidas. Nessa parte do trabalho, procurarei, a partir de contradições presentes nos discursos e práticas dos agricultores e dos professores das escolas rurais, nas quais estudam os filhos dos assentados, visualizar o confronto entre projetos de sociedade, de trabalho e de educação, que aponta para a necessidade de rever-se os modelos de escola, de trabalho e de professor, nos quais a educação básica vêm assentando suas práticas.

Ao final, é possível formular algumas conclusões de caráter provocativo que contribuam para refletir sobre as possibilidades de uma educação básica, ${ }^{2}$ afinada com as novas formas de organização da produção e, no caso da escola rural, com o mundo da cultura e do trabalho rurais. A importância da análise sobre a relação entre trabalho cooperativo e educação básica, mormente o ensino fundamental rural, que procuro fazer neste artigo, consiste em trazer elementos concretos, resultantes de pesquisas que venho realizando, para se pensar a educação básica e a formulação de políticas públicas na área da educação.

\section{Trabalho cooperativo: uma alternativa de trabalho ou estratégia neoliberal?}

O trabalho cooperativo pode identificar uma multiplicidade de experiências que nem sempre se relacionam. Vou construir o conceito tomando por base

${ }^{2}$ Não vou me deter apenas no ensino fundamental, porque a pesquisa mostra uma demanda muito forte, da parte dos agricultores assentados e seus filhos, de criação e manutenção de escolas de ensino médio, especialmente de nível técnico, na área rural. alguns elementos históricos presentes no debate sobre capitalismo x socialismo e alguns elementos das atuais discussões sobre economia solidária, ou socioeconomia cooperativa e solidária, ou economia popular solidária, ou associativismo, ou terceiro setor, ou cooperativismo... Muitos são os nomes, mas em todas essas novas modalidades de economia o trabalho cooperativo faz-se presente.

Singer (1999a) historia o surgimento das organizações cooperativas para a produção no final do século XVI, na Inglaterra, como iniciativa de artesãos organizados por associações de ofícios. Estas organizações extinguiram-se, porque não conseguiram competir com as manufaturas. Operários, inspirados em Robert Owen, retomaram, através de seus sindicatos, a criação, no século XIX, de cooperativas de produção, visando disputar o mercado com os empresários. A violenta repressão aos sindicatos que lhes davam sustentação acabou por aniquilar as cooperativas. Apesar dessa perseguição, em 1844, operários de uma indústria têxtil fundaram, em Rochdale, na Inglaterra, uma cooperativa de consumo sob o nome de Sociedade dos Pioneiros Eqüitativos. Valendo-se das experiências anteriores, estabeleceram alguns princípios (Singer, 1999a, p. 24; Rech, 1995, p. 26-34; Schneider, 1999, p. 50-52), o que possibilitou um significativo crescimento da sociedade, disseminando-se as cooperativas na Inglaterra e em outros países europeus.

Nas poucas vezes em que Marx faz referência às fábricas cooperativas, em $O$ Capital, é para ressaltar que o caráter social do trabalho "é diferente quando as fábricas pertencem aos próprios trabalhadores, por exemplo, em Rochdale" (Marx, 1982, livro 3, vol. 4, p. 96) ou para afirmar que as "fábricas cooperativas demonstram que o capitalista, como funcionário da produção, tornou-se tão supérfluo quanto o é, para o capitalista mais evoluído, o latifundiário" (Marx, 1982, livro 3, v. 5, p. 415).

Há toda uma discussão sobre o papel das cooperativas na superação do capitalismo e construção do socialismo, que envolve Eduard Bernstein e Rosa Luxemburgo (Luxemburgo, 1986; Singer, 2000), sobre os obstáculos culturais e econômicos que os cam- 
poneses enfrentam para formar e manter as cooperativas agrícolas (Kautsky, 1972, v. I, p. 161-177) e sobre a diferença entre um socialismo "cooperativo" como pura fantasia, qualquer coisa de romântico e o trabalho cultural a ser desenvolvido com o campesinato, tendo como objetivo econômico a "cooperativização" (Lenine, 1980, v. 3, p. 662). Nessa discussão, sobressai a questão cultural como um dos maiores entraves para a constituição das cooperativas camponesas, problema que ainda hoje o MST enfrenta para instituir a cooperação como princípio produtivo e organizativo.

A pesquisa histórica mostra que as cooperativas têm suas origens ligadas às lutas operárias. Segundo Singer (1997), o desemprego empurra os desempregados inicialmente para a produção autônoma, que não sobrevive porque a demanda por seus produtos é pequena e, ainda, porque a pressão da grande empresa e o peso dos impostos permite um número muito limitado de consumidores. Outra iniciativa dos desempregados é o trabalho cooperativo. Singer agrupa experiências novas no âmbito do trabalho cooperativo sob o nome de economia solidária, que entende como:

Todas as formas de organizar a produção, a distribuição e o crédito por princípios solidários. Entre estas formas, as cooperativas são as mais antigas e melhor conhecidas, mas a elas somam-se outras como os "clubes de trocas" (formados por pequenos produtores que usam de moeda própria para intensificar o intercâmbio entre eles) e os "bancos do povo" (cooperativas de crédito dirigidas aos mais pobres, cujo crédito é garantido pelo compromisso solidário de grupos formados para este fim. (Singer, 1999a, p. 27, nota)

As experiências de trabalho cooperativo ampliamse em momentos de desemprego, como o atual, tendo decrescido no período em que vigorou o Estado do bemestar associado ao modelo fordista de produção. Segundo Singer (idem, p. 26):

o novo cooperativismo constitui a reafirmação da crença nos valores centrais do movimento operário socialista: democracia na produção e distribuição, desalienação do trabalhador, luta direta dos movimentos sociais pela geração de trabalho e renda, contra a pobreza e a exclusão social.
Mas pensa Singer que o trabalho cooperativo também tem gerado abusos ao respaldar a contratação dos serviços de cooperativas de trabalhadores pela empresa capitalista que se desobriga do pagamento dos encargos sociais referentes aos direitos trabalhistas. Gaiger (1999) também recomenda cautela acerca de uma visão excessivamente otimista do trabalho cooperativo, pois é preciso aprofundar o conhecimento dessa nova realidade antes de demarcá-la, tendo presentes as contradições, ambigüidades e multiplicidades de interesses que a atravessam.

Gaiger reconhece a existência de diferentes formas de associações de trabalhadores para a geração de trabalho e renda sob os princípios da cooperação. Diferente de Singer, que organiza tais experiências sob a denominação de economia solidária, Gaiger acrescenta o termo popular, ou seja, economia popular solidária, para designar um fenômeno novo, referente a uma realidade heterogênea que ainda apresenta uma série de questões aos pesquisadores. Tais formas de atividades econômicas envolvem diferentes setores produtivos e categorias sociais mescladas, que se organizam também de formas variadas em associações, cooperativas, empresas de pequeno e médio porte. Suas origens tanto podem basear-se em vínculos comunitários ou familiares como podem resultar de lutas coletivas de trabalhadores urbanos e rurais a partir de mobilizações de caráter político (Gaiger, 1999, p. 29). Para o autor, é possível focalizar essa nova realidade tanto sob o prisma de uma economia alternativa, porque diferencia-se das relações fundadas na lógica capitalista, quanto sob o prisma das alternativas econômicas, que podem significar empreendimentos viáveis com os quais os trabalhadores desempregados possam vir a recriar suas vidas, tendo-se o cuidado para não perder de vista os limites e contradições dessas novas experiências. Quanto aos limites, o autor refere-se ao fato de empresas privadas, com incentivos estatais, constituírem cooperativas de trabalhadores em regiões fracamente sindicalizadas para eximirem-se dos encargos sociais que passam a ser da responsabilidade dos trabalhadores autônomos. Ocorre, então, para os sócios arregimentados dessas falsas cooperativas, um 
retrocesso em relação ao assalariamento e não um processo de emancipação (Gaiger, 1999, p. 30).

Arruda, em participação no Seminário de Avaliação de Experiências de Economia Solidária, organizado pela Cáritas/RS (15/04/99), sugere a denominação de socioeconomia cooperativa e solidária para agrupar as experiências de trabalho cooperativo. $\mathrm{O}$ caminho cooperativo (Arruda, 1996) precisa ser construído pelos trabalhadores e suas organizações, visando, ao mesmo tempo, superar a cultura da reivindicação e da delegação e criar ambiente propício a que tais trabalhadores tornem-se sujeitos conscientes e ativos do seu próprio desenvolvimento. Para isso, é necessário ocupar os espaços econômico, político, informativo, comunicativo e cultural.

Em seu estudo sobre o associativismo, Gohn (1998) analisa o crescimento das organizações nãogovernamentais (ONGs), que conquistaram autonomia em relação a partidos e sindicatos, constituindo-se algumas como empresas cidadãs, ou terceiro setor, que desenvolvem novas formas de associativismo e poder local. Segundo a autora, as ONGs agem no vazio provocado pelo desmantelamento do Estado do bem-estar, reformulando o discurso da conscientização e dando ênfase a trabalhos de geração de renda em cooperação e parceria com o Estado, tendo por objetivo criar canais de inclusão. Essas organizações atuam em um cenário no qual a organização popular apresenta aspectos bastante contraditórios em que se distinguem, nas cidades, as novas práticas de participação, os espaços públicos não-estatais, as redes de composição sociopolítica diferenciada e, no campo, o recrudescimento das lutas sociais. Nesse contexto, conforme Gohn, o associativismo urbano caracteriza-se pela mobilização local e por redes de solidariedade, não cobrando o compromisso da militância. Aqui, o princípio da participação é fundado na solidariedade ao redor de causas, não possui uma identidade de classe, mas uma identidade mais complexa, abrangendo cor, raça, sexo, nacionalidade, idade, herança cultural, religião, culturas territoriais, características sociobiológicas etc. (Gohn, 1998, p. 19). Já as lutas sociais no campo são lideradas pelo MST, que tem sua base na área rural mas conta com instâncias organizativas e entidades de apoio na área urbana. No meio rural, o trabalho cooperativo significa a possibilidade de trabalho e construção de espaços de autonomia do trabalhador, conforme Gohn. O MST continua a apoiar a organização dos agricultores mesmo depois de assentados, através de assistência técnica, organizativo-política e na área da educação. Em estudos mais recentes, Gohn (2000, p. 60) evidencia a existência de ONGs contradições na atuação das ONGs, que incluem tanto entidades progressistas como conservadoras.

O crescimento e a despolitização das ONGs, a substituição do trabalho político-organizativo pelas empresas cidadãs, as relações do chamado terceiro setor com o Banco Mundial, visando obter financiamentos para aplicar em políticas sociais que originalmente deveriam estar a cargo do Estado, são outras questões que acrescento às que merecem aprofundamento, da parte do pesquisador, para análise das experiências associativas vinculadas àquelas organizações e empresas. Ao invés da conquista da autonomia, as experiências organizadas sob a orientação de tais entidades poderão significar a manutenção do individualismo e da dependência através de trabalhos meramente assistenciais.

Tiriba (1998) preocupa-se em saber como trabalhadores sem ou com pouca escolaridade conseguem organizar-se e gerir a produção. No estudo que faz sobre as organizações econômicas populares (OEPs), identifica-as como resposta ao desafio do desemprego, uma vez que a luta pela vida é que move os pobres. Apesar disso, como os demais autores, Tiriba reconhece que as OEPs apresentam contradições; elas tanto podem reproduzir o sistema de exploração e ser funcionais ao processo de acumulação de capital, liberando o Estado de sua função de prover políticas sociais, quanto podem ser germes de uma nova cultura do trabalho e uma alternativa ao desemprego como parte de um projeto de transformação social. A autora denuncia que Estado e empresas estimulam o cooperativismo e o auto-emprego para conter conflitos gerados pelo desemprego e pelo neoliberalismo, em que o Estado se exime do papel de provedor das políticas sociais. Gran- 
des firmas contratam serviços de cooperativas que competem entre si, acabando por destruirem-se. No sentido inverso a este movimento neoliberal, a autora destaca ações de entidades que lutam por direitos sociais, ONGs e universidades, que assessoram experiências de associativismo. Como Gaiger, pensa Tiriba que seja preciso aprofundar o conhecimento acerca da complexidade das ações e significados que constituem a economia popular. As experiências de economia popular não se afirmam como concorrentes ao capital, mas são influenciadas pelo mercado; não estão prontas, mas sinalizam para novas formas de organização do trabalho.

Em sua análise, Tiriba levanta uma série de questões sobre a incorporação ou não de novas tecnologias, sobre as relações de trabalho, sobre a relação com os consumidores e sobre a organização do processo de trabalho nas OEPs. Para o que me proponho como objetivo de pesquisa interessa a questão do conhecimento do trabalhador, abordada pela autora. Pelo fato de o mesmo não ter freqüentado a escola, seu conhecimento restringe-se ao saber prático. Este saber vai-se ampliando no processo de consolidação da experiência de trabalho cooperativo, mas não se pode concluir, apressadamente, que prescinde do saber escolar. É preciso criar formas de organização do trabalho e da escola, nas quais o trabalhador possa ter acesso ao desenvolvimento tecnológico e aos fundamentos do trabalho e da sociedade, tendo como princípio a autogestão, pois

A autogestão enquanto princípio inspirador da produção associada carrega consigo o pressuposto da construção da autonomia, compreendida como um processo em que cada trabalhador, em conjunto com os demais trabalhadores, se torna sujeito inventor da vida, construtor-criador da organização da produção. (Tiriba, 1998, p. 209-10)

A economia popular solidária é uma alternativa buscada diante do desemprego e da negação dos direitos sociais, mas ela não se torna solidária só por isso; ela precisa construir-se como tal, porque os trabalhadores reunidos em cooperativas podem, seduzidos pelos apelos do mercado, ser tentados a reprodu- zir os mecanismos de exploração do capital, daí o cuidado em não idealizar as experiências de trabalho cooperativo, mas refletir criticamente, junto com os trabalhadores, sobre elas. Também é preciso atentar para a ambigüidade das ONGs, que se propõem a assessorar experiências associativas; elas tanto podem indicar o caminho da autonomia e de novas relações de trabalho, quanto podem ser funcionais à diminuição das tensões e dos conflitos sociais causados pelo desemprego.

Entre as dificuldades que enfrentam as associações cooperativas, uma delas é a ausência de uma cultura cooperativa entre os trabalhadores, segundo Todeschini e Magalhães (1999). É conhecida a tradição de trabalho em mutirão tanto entre trabalhadores urbanos quanto entre trabalhadores rurais. Essa cooperação, que pode ocorrer em determinadas situações de trabalho, de socorro em calamidades e mesmo na organização de atividades de lazer, nem sempre consegue avançar para uma associação em condições de enfrentar os desafios do mercado.

Um dos maiores estudiosos das OEPs na América Latina, Razeto (1999), concorda com os demais autores ao explicar a economia popular como resultante da conjunção de mudanças no mundo do trabalho, que são geradoras de desemprego, e de mudanças no Estado, em que as crises fiscal e administrativa reduzem sua capacidade de captar recursos para promover as tradicionais políticas sociais. A economia popular não é homogênea e pode evoluir tanto para respostas organizadas e solidárias, geralmente ligadas a setores religiosos progressistas, a partidos e sindicatos, como para situações de assistencialismo e beneficência que mantêm a dependência. Enquanto um nível mais elaborado da economia popular, o autor caracteriza a economia de solidariedade como formulação teórica na qual estão presentes alguns traços, como a solidariedade, a autogestão e a cooperação, que a diferenciam da lógica econômica capitalista. Associando economia popular e economia de solidariedade, Razeto (1999, p. 45) define economia popular de solidariedade como

aquela parte da economia popular que manifesta alguns traços especiais que permitem identificá-la também como eco- 
nomia de solidariedade, ou, pelo contrário, é aquela parte da economia de solidariedade que se manifesta no contexto da que identificamos como economia popular.

Entre os autores, mesmo entre aqueles não ligados à área da educação, há o reconhecimento de que a escola tanto pode contribuir, dotando os trabalhadores de conhecimentos que viabilizem as experiências cooperativas, quanto pode, pelos valores individualistas e consumistas que difunde, fragilizar essas experiências. Ao analisar os princípios que orientaram os Pioneiros de Rochdale, Limberger (1996, p. 12) destaca “a importância da educação cooperativa, que por sinal incluíram como uma norma básica em seu histórico estatuto [...]." Pais de alunos e professores, no entanto, concordam que a escola desenvolve a competição, o individualismo e a submissão, ao mesmo tempo em que reconhecem as dificuldades para introduzir relações de cooperação no ensino, conforme veremos mais adiante.

Singer (1999b) pensa que as cooperativas não se devem caracterizar pela exploração do trabalho e sim por relações democráticas, igualitárias e autogestionárias, isto é, socialistas. A viabilidade das cooperativas, no entanto, vai depender da capacidade de organização dos trabalhadores urbanos e rurais. Porém, "sem educar as pessoas nos valores da solidariedade, igualdade e democracia é impossível transformar todas as empresas capitalistas em autogestionárias (idem, p. 57).

Um dos grandes desafios do cooperativismo autogestionário e solidário, para Arruda (1996), é a educação integral dos associados e suas famílias. O motivo que leva os trabalhadores a organizar-se em cooperativas é ter um trabalho quando estão desempregados. Todavia,

A construção de uma cultura solidária e companheira não se dá automaticamente nem da noite para o dia. Ela é resultado de uma lenta e profunda transformação subjetiva dos próprios associados, que está ligada a processos tanto teóricos como práticos, individuais e coletivos, de educação. (Arruda, 1996, p. 43)

Ao referir-se às organizações cooperativas implantadas pelo MST, Gohn afirma que este Movimen- to procura oferecer educação diferenciada para os assentados, mas enfrenta conflitos com os valores e a formação tradicional de "ênfase à propriedade individual, produção familiar e pouco trabalho em cooperativas. As propostas socializantes de trabalho cooperado do MST muitas vezes não são bem compreendidas ou aceitas pelos sem-terra" (Gohn, 1998, p. 20).

Gadotti (1999) associa economia popular à educação comunitária, sendo esta a que vincula o produtivo, o organizativo e o educativo. $\mathrm{O}$ autor diferencia a economia informal, que responde a necessidades imediatas de sobrevivência, da economia popular, na qual estão implícitos novos valores e um projeto de sociedade. A economia popular é uma opção de vida com base em uma produção associada, a qual cria valores solidários, de participação, autogestão, autonomia e, apesar de certas ambigüidades, sinaliza para uma nova maneira de ser povo, para uma lógica de pensar, produzir e relacionar-se que difere das formas econômicas próprias do capitalismo (idem, p. 13-14). A economia popular experimenta o desafio de superar a cultura individualista em que estamos inseridos, contando para isso com a educação comunitária que não pode estar separada da educação escolar, pois os setores populares da comunidade lutam pela escola pública de qualidade (idem, p. 15).

Tiriba (1998), recorrendo a Gramsci, mostra, por meio do estudo feito sobre as OEPs, por onde podem passar os vínculos entre a educação e o trabalho produtivo nessas experiências. Segundo a autora, as organizações da economia popular são conteúdo e fim do trabalho como princípio educativo, porque este trabalho tanto é fonte de produção de bens para a satisfação de necessidades básicas materiais e espirituais, quanto é fonte de produção de conhecimentos e de novas práticas sociais. Apesar disso, não prescinde da escolarização na qual o trabalhador possa ter acesso aos instrumentos básicos para a aquisição e domínio da cultura e do conhecimento científico. A luta por uma escola pública de qualidade para todos poderia ser acrescida de um critério que colocasse a economia popular como fundamento de uma educação popular. Ainda, para a autora, a economia popular nem pode 
ser confundida com a soma de experiências de economia associativa, nem pode ser tomada como forma de complemento ao processo de acumulação de capital nos desequilíbrios causados por este e no seu processo de adaptação. A economia popular coloca-se como confronto com a economia capitalista. Portanto,

A economia popular é uma escola que deve ser vivida, não apenas para amenizar o problema do desemprego, mas para que os trabalhadores e a sociedade descubram que é possível uma nova maneira de fazer e conceber as relações econômicas e sociais - não apenas no âmbito do local de trabalho, mas também no âmbito de toda a sociedade. (Tiriba, 1998, p. 215)

Conforme visto até aqui, a economia popular solidária, com diversas designações que manifestam a heterogeneidade de experiências reunidas sob esse título, é um fenômeno que se explica pela necessidade de as pessoas buscarem alternativas de sobrevivência diante do desemprego e da crise do Estado do bemestar. Ainda não suficientemente conhecida, a economia popular solidária é atravessada pela contradição capital/trabalho que, por sua vez, marca as ações das camadas populares cujas práticas sociais, mesmo as de cooperação, estão voltadas para o mercado ao mesmo tempo em que dele tentam libertar-se, romper a relação.

Assim, se a sobrevivência das OEPs impõem-lhes relações com o mercado, a luta pela autonomia vai forjando novas formas de relações de cooperação e solidariedade que rompem com a competição e o individualismo. Portanto, o trabalho cooperativo, uma das formas de manifestação da economia popular solidária que tomo como paradigma, é aquele que se realiza no coletivo, baseia-se em relações de solidariedade e na busca da autonomia. Para isso, é fundamental que os trabalhadores associados sejam proprietários dos meios e instrumentos de produção; que o trabalho seja autogerido pelos próprios trabalhadores, ou seja, que não haja exploração de uns companheiros sobre outros, nem divisões hierárquicas na organização do trabalho entre quem pensa, administra e executa a produção/reprodução/distribuição.
A maioria das experiências cooperativas tem essa orientação como horizonte teórico possível, porém ainda bem distante de ser realizado. No caso do MST, sujeito/objeto da pesquisa, as questões acerca do trabalho cooperativo colocam-se tanto ao nível da organização do Movimento, quanto ao nível da formação escolar. Veremos, no próximo segmento, essa relação de conflitos entre as necessidades dos agricultores assentados e a formação feita pela escola, ressaltando a contradição entre os valores transmitidos pela escola e os valores exigidos pelo trabalho cooperativo. Os depoimentos foram colhidos em visitas de avaliação do Projeto Lumiar ${ }^{3}$ e em reuniões de pesquisa, que visam a formulação de políticas públicas para o trabalho, a educação e o lazer, feitas no Assentamento Conquista da Liberdade, em Piratini. ${ }^{4}$

${ }^{3}$ O Projeto Lumiar consiste em uma forma de fornecer e acompanhar o trabalho de assistência técnica aos agricultores assentados, por meio do INCRA em parceria com o MST e universidades. Sobre o assunto, ver INCRA (1996) e Ribeiro (2000). Foram efetuadas oito reuniões de avaliação do Projeto Lumiar nos assentamentos Itapui Meridional (09/08/99, com 22 assentados); Capela (09/08/99, com 11 assentados); XIX de Setembro (10/09/99, com 11 assentados); Lagoa do Junco (11/08, com 12 assentados); Viamão (31/11, com 33 assentados); Quinta ou São Pedro (22/12/99, com sete assentados) e Padre Reus-Fazenda Santa Rita (22/12/99, com 10 assentados), todos situados em municípios que integram a Regional do MST de Porto Alegre. Foi efetuada também uma reunião de avaliação do mesmo Projeto no Assentamento Conquista da Liberdade, em Piratini, com 5 assentados. Em geral, cada assentado representa um núcleo de famílias e vem à reunião após ter debatido as questões com seu grupo.

${ }^{4}$ No município de Piratini, na pesquisa em andamento, foram feitas três reuniões: uma com os poderes públicos do município, professores, diretores de escolas e representante da Secretaria Estadual do Trabalho (31/03/2000); outra na mesma data (31/03/ 2000) com 22 assentados do Conquista da Liberdade; uma terceira reunião foi realizada em 07/06/2000, com 22 professores das escolas rurais que atendem às crianças de nove assentamentos de Piratini. Os professores são designados por letras, dentro do contexto de cada questão de pesquisa a eles proposta. 


\section{Trabalho cooperativo no MST e escola básica: conflitos e questões}

Os estudos sobre educação rural no Brasil - os poucos existentes ${ }^{5} \mathrm{em}$ virtude de a agricultura familiar ser considerada um entrave ao processo de modernização do campo - evidenciam que esta modalidade de educação tem como referência a sociedade urbano-industrial (Calazans, 1993). "O descaso com a educação no meio rural tem levado a uma compreensão de que o lugar de quem estuda é na cidade e que, para continuar na roça, os trabalhadores não necessitam de estudo" (Camini, 1998, p. 37). Nessa perspectiva, os valores, os conteúdos, os modelos, a linguagem adotados pelo currículo das escolas rurais e pelas atividades extraclasse a elas vinculadas, como os clubes agrícolas, sempre estiveram em confronto com o modo de ser, de produzir alimentos e cultura dos trabalhadores rurais (Gritti, 2000; Ribeiro, 2000a). Essa desconexão entre a realidade encarnada na formação escolar e a realidade rural é percebida pelos agricultores, conforme podemos observar neste depoimento:

Com relação ao estudo, eu sou muito radical. A escola foge muito à realidade. Tu aprende coisas na escola que jamais vai ter utilidade na vida, pelo menos prá nós que vivemos da terra. Alunos que se formam não sabem de onde vêm os alimentos, como são plantados; a escola foge totalmente do nosso jeito de viver (XIX de Setembro).

O descrédito do agricultor em relação à escola é percebido pelos professores:

Eles não valorizam a educação; eles não têm uma credibilidade na educação como forma de ascensão social, nem eles nem seus pais, uma questão cultural. A credibilidade deles é na união do grupo deles como forma de adquirir al-

${ }^{5}$ Em "Levantamento Bibliográfico Parcial sobre Educação Rural", resultante do subprojeto de Patrícia Barden, Banco de Dados sobre a Escola Básica do Campo, desenvolvido por meio do Programa de Iniciação Científica $(\mathrm{CNPq})$, vinculado ao projeto $P e$ dagogias de Esperança nos Movimentos Sociais Populares, foram listados 214 títulos referentes a estudos sobre educação rural. guma coisa, de ter seus benefícios e direitos garantidos. (Professora)

Uma mudança radical vem ocorrendo na relação entre os agricultores e a escola de seus filhos. Antes, esses trabalhadores assumiam o rótulo de ignorantes, atrasados, caipiras, que thes era impingido, ou, se não o aceitavam, desenvolviam uma resistência silenciosa e amarga com o conhecimento escolar e técnico-agrícola por não encontrarem à mão uma forma mais adequada de resposta. Reconheciam a importância de seu trabalho como produtores de alimentos e, ao mesmo tempo, a necessidade de uma formação escolarizada para que os filhos pudessem conquistar um emprego na cidade; a terra era pouca para dividir e não queriam para os filhos o sacrifício do trabalho braçal sem horário, sem domingo, sem férias, sem direitos sociais conquistados pelos trabalhadores urbanos (Ribeiro, 2000a).

Professores que trabalham com filhos de agricultores assentados e não assentados, nas escolas rurais visitadas, identificam atitudes e visões de mundo diferentes entre aqueles que ainda desenvolvem agricultura familiar isolada e aqueles que já vivenciaram a experiência coletiva de luta pela terra e desenvolvem, nos assentamentos, alguma forma de trabalho cooperativo.

O sonho do pequeno agricultor é morar na cidade, eles acham que na cidade é tudo uma beleza; aqueles mais humildes o sonho do pai é ganhar uma casinha e morar na cidade para ter tudo... E eles estão com a mentalidade que o campo é só trabalho, sofrimento e quando na realidade é na cidade que eles vão encontrar as maiores dificuldades. (Professora A)

A visão que eu tenho é diferente, eu trabalho com vários assentamentos (...). Então, por nada deste mundo eles querem voltar para a cidade; eles querem continuar aqui, sem água, sem luz, mas ficarem por aqui. A maioria já passou necessidades e eles acham que aqui é melhor... (Professora B)

É, aqueles dos assentamentos já vivenciaram, então já sabem que lá também é difícil, só que estes (refere-se aos filhos dos agricultores familiares) que não viveram na cida- 
de, então eles têm a ilusão da cidade, de uma opção melhor de vida. (Professora C)

O desemprego na cidade e no campo e as lutas pela terra organizadas pelo MST têm desenvolvido nos agricultores consciência da necessidade de criar formas de plantar-se na terra de modo que dela não possam ser arrancados, consciência esta que aos poucos descobre a importância de ocupar a escola como espaço de aquisição de instrumentos lingüísticos, de cálculo, de compreensão da sociedade, de luta pela terra, de conquista de direitos.

Se a educação é um direito social, é também para os sem-terra do MST hoje um dever político [...] à medida que os novos desafios exigem uma intervenção cada vez mais qualificada em termos de análise da realidade e dos próximos passos a dar em cada conjuntura. (Caldart, 2000, p. 177)

Portanto, a escola que historicamente vem dando as costas a agricultores e agricultoras pode significar instrumento de luta para permanecer na terra, de compreensão dos mecanismos de administração de recursos, de gestão da produção, de conquista de mercados. Percebendo a importância da formação escolarizada para a consolidação de seus propósitos de permanência na terra em torno da organização do trabalho cooperativo, o MST forja sua própria concepção/prática de escola em que

Ensinam-se técnicas e procedimentos agrícolas desde tenra idade, e toda a alfabetização tem como exemplo a realidade imediata que vivenciam. Busca-se desconstruir ou reverter a tendência, dominante no campo e nas práticas escolares tradicionais, de desvalorização do homem do meio rural, de glorificação das cidades e a sua visualização como ponto máximo de realização do homem do campo, com a sua ida para a cidade. (Gohn, 1997, p. 46).

Essa conquista da escola passa por um longo processo já analisado por alguns autores, entre os quais Camini (1998) e Caldart (1997 e 2000). Para o que me propus neste texto, analisarei as concepções contraditórias que transparecem nas falas de representantes do município: funcionário, professores, diretoras e dos próprios agricultores assentados. A discordância entre a "escola estruturada normalmente" e as demandas do Movimento evidencia um confronto maior de projetos de sociedade e de educação, presente nas falas dos professores, em que aparece a rivalidade entre a população que já vivia no município e a população de agricultores assentados. "Existe uma certa rivalidade entre Piratini e os assentamentos" (Professora A). "O pessoal ainda vê o povo do assentamento como aquele povo marginalizado, que está tirando o espaço deles, que veio prá incomodar" (Professora B). "Porque o prefeito só faz estrada no assentamento, não cuida das outras estradas" (Professora C). "Inclusive numa festa da comunidade eu tentei me aproximar das meninas (assentadas) para elas virem para o nosso grupo, mas elas ficam no grupo delas, não sei o que elas pensam que vai acontecer se houver integração, eles procuram se afastar" (Professora D). O conflito entre assentados e agricultores familiares é uma constante em todos os municípios onde existem assentamentos. Esse conflito entra na escola, como mostra a reportagem Bandeiras do MST causam atritos (Zero Hora, 8/9/ 2000, p. 24), que trata dos festejos da Semana da Pátria, da Escola Nova Sociedade, em Nova Santa Rita.

A presença do MST na escola, através dos alunos, rompe os tradicionais "consenso" e "harmonia" que pareciam reger as atividades escolares, instaurando a divergência e o conflito entre professores, suas concepções de mundo, de trabalho e de educação.

A gente não conhece muito a política de reforma agrária, a gente não sabe o que o município ganha; só que eu acho que de repente existe uma invasão, eles ganham a terra; não existe ninguém preparado para as consequiências. Não sei como é esta organização. (Professora A)

Eu sou extremamente a favor da reforma agrária, porque onde é que estariam estas crianças nossas aqui se não tivessem esses assentamentos? Onde estariam? Em que favela? (Professora B)

Com todas as contradições peculiares à realidade de serem agricultores sem-terra em um país periférico, que não conseguiu superar a estrutura agrária baseada no latifúndio, os integrantes do MST afirmam- 
se no processo de luta pela Reforma Agrária como sujeitos sociais à medida que fincam suas raízes na terra e na sociedade, gestando novas relações de trabalho, de produção, de cultura, de poder e de lazer.

A cooperação é uma prática espontânea, não refletida, que, como a solidariedade, está incorporada às relações de trabalho que caracterizam a agricultura familiar. Resgatando essas práticas, o MST fez delas princípios a serem incorporados como valores refletidos e cultivados pela organização dos trabalhadores sem-terra. Esses valores começam a ser vivenciados desde o processo organizativo que antecede a ocupação, mantêm-se durante a ocupação e a instalação do acampamento e parecem afirmar-se na organização das diferentes equipes que garantem a permanência das famílias acampadas debaixo das lonas pretas. Porém, é quando se dá a desapropriação da terra e a entrega dos lotes que o enraizamento desses valores começa a ser testado na organização dos grupos de famílias e das cooperativas de produção.

A gente tava se acostumando com o coletivo, tinha pouca coisa e repartia prá sobrevivê. Só que cooperativa não é assim; a gente confundiu trabalho coletivo com empresa e empresa precisa capital, registro, burocracia. Como vamos manter uma empresa? Outra coisa, pessoas de raça diferente, costumes diferentes, regiões diferentes, pensa diferente. Também não deu certo devido à área que não consegue produzir. O trabalho individual também não dá muito resultado, o trabalho coletivo foi importante, o erro foi pensar a cooperativa como empresa... (XIX de Setembro)

A continuidade do trabalho cooperativo iniciado no acampamento é um desafio para o MST ao constituírem-se os assentamentos. Há assentamentos que reúnem famílias provenientes de aproximadamente 20 municípios, como é o caso dos assentamentos de Piratini. Entre os assentados há descendentes de alemães, italianos, negros, índios, mestiços e há brancos que não reivindicam outra origem que não seja a brasileira. Isso explica a diversidade de concepções de trabalho, cooperação, compromisso. As experiências com determinadas culturas, como por exemplo o plantio de milho e soja ou o cultivo tradicional de arroz, nos lugares de origem, também dificultam a adaptação e o aprendizado para a construção de matrizes produtivas viáveis de acordo com o solo e o clima, como frutas, leite e arroz pré-germinado ( $\mathrm{Ri}$ beiro, 2000b e 2000c). Os próprios agricultores reconhecem estas dificuldades como desafios colocados ao movimento.

A cooperação é um desafio, uma busca que está se construindo desde o Movimento. Mesmo as famílias que não têm uma cooperativa, um grupo produtivo, têm seu trabalho de cooperação dentro do Assentamento. (Conquista da Liberdade)

Ao mesmo tempo, os agricultores têm consciência dos valores individualistas incorporados a sua formação, como entraves ao trabalho cooperativo, ao processo de readaptação às novas formas de vida nos assentamentos e ao enfrentamento das diferenças culturais.

Cooperação é bem maior do que cooperativa. Achamos que é a saída, mas na nossa cabeça ainda está a cabeça tradicional. A cooperativa é estratégica, ela sofre as mesmas restrições. Ela consegue planejar melhor sua mão-de-obra, liberar uma pessoa prá participar do Movimento. Uma dificuldade é a nossa cultura de artesão, egoísta... (Conquista da Liberdade)

A cooperativa tem organização e horário; já temos um grupo de famílias. Fazemos mutirão, cada um sabe onde é a sua parte; o uso é coletivo; tá dando mais ou menos certo. É diferente da empresa; o trabalho coletivo não precisa se aproveitar do trabalho do outro. A política agrícola do governo não estimula a cooperação. $\mathrm{O}$ individualismo ainda é forte, mas acredito que o trabalho só funciona com cooperação. (Viamão)

Dão-se conta os agricultores, todavia, que o trabalho individual dificilmente poderá garantir a permanência na terra.

No sistema capitalista, a produção individual é mais difícil. A lavoura é a longo prazo e o trabalhador precisa de um ganho prá sustentar a família. Com a cooperativa tem condições de diversificar atividades. (Lagoa do Junco) 
Há diferentes formas de cooperação que podem começar com a associação de um grupo de famílias para a aquisição de um trator, para o aluguel de um transporte para a produção, até chegar a formas mais sofisticadas de cooperativas de produção, registradas como empresas, fazendo uso de computadores, calculando custos e investimentos... No que concerne à escola básica, o trabalho cooperativo, enquanto princípio e valor para o MST, enfrenta duplo desafio que se traduz nas suas relações cotidianas com a escola dos filhos e nos valores, tanto os incorporados a sua formação quanto os que são transmitidos aos filhos.

Reconhece um dos representantes dos poderes públicos municipais que

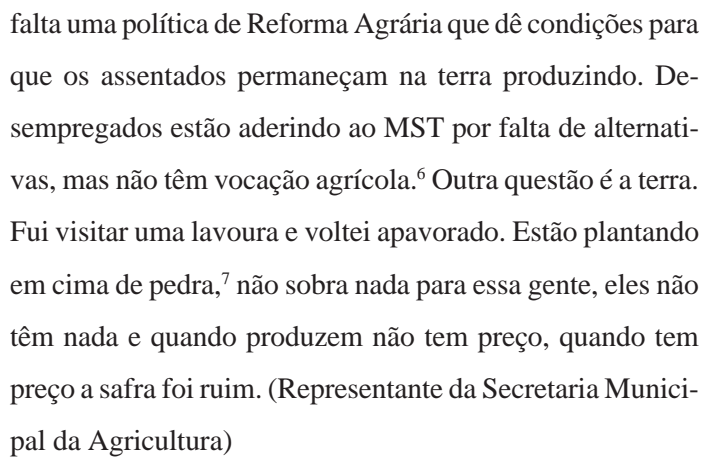

A relação entre o MST e a escola, que vem sendo analisada por diferentes pesquisadores (Camini, 1998; Lucas, 1999; Caldart, 2000), mantém-se conflituosa, conforme veremos nos depoimentos a seguir.

Nós conversamos prá botar uma bandeira do Movimento na escola e uma ordem da Secretaria de Educação diz que não pode botá bandeira na escola. Outra dificuldade que

${ }^{6}$ No Assentamento Padre Reus (Fazenda Santa Rita), 80\% das famílias eram compostas de agricultores que se tornaram sapateiros e quando houve a falência das empresas de calçados uniramse ao MST em busca de terra para sobreviver.

${ }^{7}$ Alguns assentamentos da Regional de Piratini apresentam terreno extremamente pedregoso, mata nativa e animais silvestres, como queixadas e veados. Nesses assentamentos, dos quais diz-se que são "pedra, mato e morro", os agricultores estão enfrentando graves dificuldades para produzir feijão e milho e para comercializar tal produção. enfrentamos prá fazê discussão sobre a escola é que a cada seis meses trocam os professores. ${ }^{8}$ (Conquista da Liberdade)

Se vou para a escola e na escola me dizem que devo respeitar a autoridade, eu devo aceitar a democracia, o governo democrático que foi eleito pelo povo que está aí, não imposto por ninguém, e aí eu vou prá dentro da minha casa e digo assim: não conseguiu como tinha que ser vamos tomar, vamos invadir, vamos nos apossar, e entra em confronto também dentro da educação e fica sério porque dentro da escola eu acho também que posso fazer o que eu quero. Professor não me manda, professor não me segura. Temos isso dentro do município que é um problema sério. O governo não dá estrutura para o município, os colonos chegam fazendo exigências; não há uma política agrária neste país.

(Diretora de escola de Piratini)

Ao mesmo tempo em que é reconhecida a legitimidade das aspirações do Movimento, em termos de uma política agrária, não são aceitas as formas de luta adotadas pelo MST. Mas o conflito entre a escola e o agricultor é mais antigo, conforme já afirmei, e começa a aparecer tanto nas falas de professores e diretores, quanto nas falas dos agricultores.

Tem escolas de assentamentos, não as constituídas de município ou de Estado, mas as tais escolas de assentamentos, as itinerantes ${ }^{9}$ e eu sou radical em dizer o seguinte: é a escola do papel porque consta como existente e é mentirosa. Ainda este ano passado recebemos dois alunos de terceira série que não sabiam distinguir as letras, não liam. Então não adianta fazermos belos papéis, belos discursos, colocarmos como verdades e estarmos prejudicando populações, como as crianças. Pelo que eu li das escolas itinerantes, são muito bem boladas, muito bem estruturadas no papel, mas não funcionam porque quando ele chega dentro de uma escola estruturada normalmente ${ }^{10}$ ele não vai conseguir acom-

${ }^{8}$ Lucas (1999) e Caldart (2000) registram a situação de imposição às professoras para que trabalhem em escolas nas quais haja a presença de assentados, havendo casos em que o envio da professora para tais escolas tem o significado de uma punição.

${ }^{9}$ Sobre escolas itinerantes do MST, ver Camini (1998).

${ }^{10} \mathrm{O}$ grifo é meu e tem a finalidade de ressaltar a concepção de escola que, a partir das observações feitas, parece ser a predominante. 
panhar, ele não vai ter condições de seguir um estudo já organizado diferentemente. (Diretora de escola)

Um problema que nós temos encontrado também é quando chegam essas pessoas, os assentados, é que os filhos não trazem documento algum, nenhum registro. O professor fica sem saber em que série colocar. A gente sabe, existe burocracia, e tem que existir alguma mesmo. Então a gente tem essa dificuldade... que os pais saíssem de um lugar e levassem a documentação dos filhos, porque muitas vezes a gente sabe que saem às pressas, saem de noite, abandonam a escola e não solicitam transferência. (Professora A)

Entre as próprias professoras municipais não há concepção consensual a respeito da escola itinerante, resposta encontrada pelo MST para dar continuidade à educação escolar dos filhos durante os longos períodos que duram os acampamentos, em que as famílias esperam pela desapropriação da terra para serem assentadas.

Eu tenho na minha turma duas crianças de escola itinerante. Então a gente sabe que eles perdem, porque eles não saem de lá e são colocados direitinho no lote de terra, a gente sabe que eles passam por acampamento, passam por um monte de dificuldades e eles perdem... Eu tenho até três alunos que chegaram sem registro. Eu não quero discordar da (nome da diretora), mas eu tenho alunos da escola itinerante que são maravilhosos, não sei se são exceções, mas são alunos que conseguem acompanhar. (Professora B)

Essa contradição entre o conhecimento "legítimo", transmitido pela escola, e o conhecimento construído nas lutas e nas práticas sociais, que tanto pode ser considerado marginal e sem valor, quanto pode ser considerado subversivo, contrário à ordem estabelecida, não aparece apenas entre os professores; é comum também entre os pais assentados que se identificam com o movimento, mas querem assegurar uma formação "legalizada", que dê condições (informações e certificados) para que os filhos conquistem um emprego.

Uma mãe chegou e disse: meus filhos estavam na escola do acampamento, mas eu gostaria que eles retornassem à série anterior porque eles não foram trabalhados adequadamente como deveria ser na escola. O que foi mais traba- lhado foi a questão do MST, e essa questão da disciplina não foi bem desenvolvida e eu gostaria que eles retornassem até porque não tinham documento. (Professora C)

As falas mostram que as professoras não têm visão homogênea do MST e de sua proposta de escola; mostram também que a concepção e as práticas da escola itinerante começam a colocar em questão a "escola estruturada normalmente". A contradição, que aparece no relato da professora acerca do pedido da mãe para que os filhos retornassem à série anterior, aparece também nas falas dos agricultores que, ao mesmo tempo em que criticam a escola, não vêem outra alternativa se não a de instruir os filhos para que escapem à sina da agricultura.

Nós temos dois professores que são do Assentamento. Temos que manter a história do Assentamento como atividade. Mas está colocada uma questão bem prática: saiu daí ou pára de estudar ou vai estudar na cidade... (Capela)

A escola tem um caráter bem abrangente, só que na prática... Em torno de $50 \%$ dos alunos não são filhos de assentados, mas são filhos de pequenos agricultores-familiares como nós, que têm uma mentalidade muito diferente da nossa. Jamais aceitam sentar para discutir as coisas em conjunto. Eles são auto-suficientes, não aceitam assistência técnica, eles é que sabem... São poucos os que têm atividade direta com a agricultura. Como é um colégio democrático, a maioria dos pais e alunos que não tem interesse decide. (Itapui Meridional)

Existe uma escola até a $3^{\mathrm{a}}$ série no Assentamento. A $4^{\mathrm{a}}$ série é feita em outra escola. Queríamos uma escola até a $4^{\mathrm{a}}$ série no Assentamento, mas o prefeito quer tirar a escola do Assentamento. No Segredo Farroupilha ${ }^{11}$ tem uma escola com $1^{\circ}$ grau completo, com currículo normal que não tem enfoque voltado para os movimentos sociais. Não tem nada sobre a realidade agrícola. (Quinta)

As crianças que estão estudando elas participam do processo de cooperativa do Assentamento. Mas nós nos perguntamos: nossos filhos que estão estudando fora do Assen-

${ }^{11}$ Segredo Farroupilha é um assentamento situado em Encruzilhada, como o da Quinta e o Padre Reus. 
tamento (a partir da $4^{\mathrm{a}}$ série) vão voltar para o movimento? Isso ninguém tem certeza, assim como qualquer filho de agricultor familiar que vai estudar na cidade e a gente não sabe se volta. Essa é uma preocupação, um desafio do movimento. Queremos que eles estudem porque têm direito, um direito que nos foi negado. Como organizar os assentamentos de modo a garantir que os nosso filhos possam assumir a organização, fazer parte dela e tocar? (Conquista da Liberdade)

O filho acompanha o pai, mas a idéia do pai assentado é que o filho consiga se formar em alguma coisa por causa da situação da agricultura hoje. A gente já se sente mal de estar na agricultura, não porque não ame a terra mas porque não vê o horizonte na frente pra desenvolver alguma coisa. E tu vai querê que o teu filho siga nestas condições? Vai querê dá estudo pra ele se formá em alguma coisa... Quando tu vai pra uma luta, tá lutando por direitos e o filho tá entendendo e ele depois vai trabalhá no teu lugar. (Conquista da Liberdade)

Ao mesmo tempo em que reconhecem na formação escolar uma alternativa possível para a sobrevivência dos filhos, tendo em vista o descaso com que o Estado brasileiro trata a agricultura, os agricultores assentados criticam o ensino tradicional que não inclui em suas atividades nem a cultura, nem os valores vinculados ao trabalho agrícola. A discriminação aos assentados, pejorativamente chamados de "colonos" ou "bagualada", é feita tanto pelos filhos de não-assentados, embora seus pais em grande parte sejam ligados a atividades rurais, como por alguns professores, havendo casos de brigas violentas na saída das escolas. Segundo o depoimento dos professores entrevistados, essa discriminação diminuiu bastante; segundo o depoimento dos assentados, ela ainda permanece.

O ensino ainda é o tradicional, foge totalmente a nossa realidade, só faz confundir a cabeça da gente porque lá a teoria é uma e aqui a prática é outra. Tem aluno que tem vergonha de dizer que é assentado prá não ser discriminado. Nós temos diretores que submetem os professores a dar aquela aula tradicional e também tem jovens esperando fazer 16 anos ou mais prá se mandar... (Lagoa do Junco)

O Assentamento possui uma escola de $1^{\mathrm{a}}$ a $3^{\mathrm{a}}$ série com 24 crianças e dois professores municipais que se identi- ficam com as lutas do MST. Os problemas acontecem quando as crianças vão para a escola de $4^{\mathrm{a}}$ e $5^{\mathrm{a}}$ série porque as crianças são discriminadas, se há problemas os assentados é que são os acusados. (Padre Reus)

As questões que focalizam a relação entre a escola e o MST, tendo como tema o trabalho cooperativo, aparecem mais por ocasião da pesquisa, cuja preocupação central é a formulação de políticas públicas para o trabalho, a educação e o lazer. Antes, porém, de abordar a relação entre o trabalho cooperativo, desenvolvido pelo MST, e o ensino fundamental, desenvolvido pelas escolas rurais visitadas, trarei para o debate a relação entre o trabalho agrícola, que basicamente tem na família a sua força de trabalho, e o trabalho escolar, que significa lazer se comparado ao trabalho na lavoura; significa também grandes distâncias a percorrer e o conflito entre ano agrícola (plantio e colheita) e ano letivo (currículo escolar).

Tem muitos alunos que vêm para a escola para se livrar do trabalho em casa. (Professora A)

Os alunos também vêm para a escola para se livrarem do trabalho puxado; muitos alunos pequenos trabalham; eles colocam essa vivência na sala de aula. (Professora B)

As crianças são responsáveis pelo serviço, pela produção; crianças que chegam a levantar às três da manhã para buscar feijão ou milho que ficou na lavoura, para não molhar. Elas passam o final de semana trabalhando; elas não têm lugar; eu acho que o lazer delas é na escola, na hora do recreio que eles podem jogar e na hora da educação física que fazem jogos. (Professora C)

Ao esforço e tempo despendidos no trabalho agrícola é acrescentado o esforço e o tempo gastos no trajeto entre a casa (onde se situa o lote) e o lugar onde passa o ônibus municipal que faz o transporte escolar.

Existem vários assentamentos extremamente pobres, que eles caminham dez quilômetros para chegarem à escola e chegam aqui cansados, sem ânimo e chegam na sala de aula tão tristes, sem motivação, que eu acho que nem encontram razão para participar, nem se consegue trabalhar direito em sala de aula. (Professora A) 
Às vezes é impossível caminhar de oito a dez quilômetros para pegar o ônibus debaixo de chuva. (Professora B)

Eles ficam aqui na estrada e têm que vir a pé e no outro dia a criança fica meio enfraquecida. Tem crianças que nós chegamos em casa e eles ainda estavam no meio do caminho; e é isso que a gente observa, esta distância afastando o pessoal do assentamento. (Professora C)

Quando chove a gente não pode dar presença, mas eu fico muito triste, pois imagine um dia como hoje (chovia bastante no dia da entrevista) uma criança caminhar dez quilômetros (Professora D).

Já foram efetuadas muitas críticas à inadequação entre o ano agrícola e a organização do ano letivo, orientado por uma cultura urbana, o que se reflete nas faltas dos alunos.

Eu acho que se comentou sobre as faltas dos alunos na época de plantio e colheita, que é esse um dos problemas que se tem enfrentado aqui na escola, onde se tem que estar chamando o aluno porque ele tem que ajudar o pai no trabalho. (Professora A)

São alunos que faltam, pois eles me dizem que tiveram que ir pra lavoura e eu digo, estão faltando a escola, ao que eles respondem que têm que ajudar os pais. (Professora B)

A gente tem que ver que nós estamos trabalhando no meio rural $[. .$.$] . Eles trabalham todo o sábado, todo o do-$ mingo; faltam muito; ficam às vezes uma semana sozinhos em casa. (Professora C)

Nunes (1998, p. 130) reconhece que as crianças da zona rural precisam estudar para que produzam formas de pensar e agir contrárias aos interesses do capital, mas também precisam trabalhar dado o nível de pauperização em que vivem suas famílias, sendo o trabalho, em muitos casos, uma necessidade mais do que básica para saciar a fome do dia.

As professoras percebem, porém, que, apesar das dificuldades que os alunos assentados encontram para frequientar a escola "eles gostam de estudar, pois eles têm argumentos, são criados em um meio em que os argumentos são fortes e as polêmicas também" (Professora A); "...eles têm uma vivência, principalmente assim, eles têm uma atividade mental, um raciocínio lógico bem diferente dos outros, os problemas são re- solvidos de um modo diferente dos outros" (Professora $\mathrm{B})$.

A concepção de educação como um direito de cidadania é contraditória nas práticas escolares. De um lado, há uma preocupação em saber as causas das faltas dos alunos, em compreendê-las e em chamar os pais à responsabilidade para que participem mais ativamente da vida escolar dos filhos. De outro, as escolas criam formas de contribuições "espontâneas", nas quais transparece o repasse, para os pais, do dever do Estado no que concerne a sua função constitucional de prover a escola básica das condições indispensáveis para a oferta do ensino fundamental. Alunos são estimulados a contribuir, na falta de dinheiro, com produtos transformados em votos para a eleição da "caipirinha", ${ }^{12}$ cuja justificativa dada é "fortalecer" a merenda escolar. Contraditoriamente, alunos que trouxeram suas contribuições não podem participar da festa, porque não têm dinheiro para comprar fichas para as brincadeiras ou pipocas nas barraquinhas. Sem essa contribuição, entretanto, compromete-se a merenda e uma das ocasiões de lazer coletivo da escola. Dizem as professoras:

Eu tenho muita pena dos alunos porque eles contribuem para fazer a festa e, às vezes, não vêm porque a pipoca é vinte e cinco centavos... Eu quando era criança não tinha dinheiro para comprar nada nas festas juninas. (Professora A)

Eu não cheguei a expor para os meus alunos que era obrigado a trazer porque a gente trabalha com um nível de alunos que a gente sabe que eles vão sugar o máximo os pais e trazem... E no dia ficam na tua volta querendo saber no que podem participar porque eles não têm dez centavos para nada. Aí, no outro dia, a gente ouve o seguinte; vem o filho de alguém e participa e aí eles comentam que a criança é rica porque conseguiu participar da festa e ele não. (Professora B)

Uma das diretoras reconhece que tanto a educação que recebemos quanto os currículos dos cursos em que se formam os professores não contemplam questões relativas ao trabalho cooperativo.

\footnotetext{
${ }^{12}$ Rainha caipira nas festas juninas.
} 
Quando a senhora coloca cooperativismo, a questão de associações, nós não fomos educados com cooperativismo. Pra nós professores isso é muito difícil trabalhar dessa forma. Então os conflitos se dão aí também. Como é que nós professores vamos nos adequar para trabalhar dessa forma, se nós, lá na nossa vida privada, estamos com a cabeça capitalista, quanto mais eu conseguir melhor pra mim. (Diretora de escola)

Mas essa consciência do antagonismo entre os valores de cooperação, solidariedade e autonomia, implícitos na proposta do MST para as cooperativas, e os valores da competição, do individualismo, da dependência, próprios do capitalismo, incorporados ao nosso cotidiano e implícitos, inclusive na educação escolar, aparece também nas falas dos agricultores assentados: ${ }^{13}$

Fomos educados para a competição, para sermos submissos, subordinados... não fomos educados pra ser cidadão livre, sujeito da história [...]. A educação que a gente precisa desde lá do primário, secundário até os cursos superiores, tem que ser voltada para a formação do ser humano, de novos valores, valores de solidariedade, de sentimento, da participação na sociedade como um todo. (Agricultor A) [...] porque na experiência de cooperação que a gente tem, a gente tem sofrido isso, essa cultura que a gente trouxe desde a educação do jeito da gente sobreviver. É um desafio, é um problema pra gente superar os desafios que tem, com esses novos valores de solidariedade, de cooperação, de compreensão. (Agricultor B)

Os trabalhadores assentados, mesmo denunciando os limites da formação escolar, tanto no que concerne aos conteúdos quanto no que concerne aos valores, reconhecem a contribuição da formação escolar para a consolidação das cooperativas.

É bem mais difícil trabalhar com o companheiro analfabeto do que com um companheiro mais instruído no senti-

${ }^{13}$ Nesta parte do trabalho, aparecem as falas dos assentados, que serão designados por letras, registradas na entrevista realizada em Piratini, em 31/03/2000. do da escola, então eu acho que a escola tem muito a contribuir nesse sentido, que eu dizia de trabalhar com a questão da solidariedade, da fraternidade que hoje a escola, pelo contrário, ensina individualismo e se tiver que pisar no pescoço da mãe dele para crescer na vida, faz, é o que a escola tradicional faz. (Agricultor C)

A escola não propicia muito hoje o ensino e a técnica, onde a gente estudou, a maioria de nós até a $5^{\mathrm{a}}$ série, de você fazer o planejamento da produção, fazer apontamento de custos, estudo de viabilidade. Então isso é um problema que a gente tem até hoje dentro da cooperativa, insegurança em quê investir, para onde você vai direcionar os recursos para investimento na área de produção e até mesmo no trabalho. (Agricultor D)

Os agricultores começam a enxergar a possibilidade de que a formação técnica e superior possa encontrar, ao invés de emprego, trabalho no campo e, mais do que isso, possa qualificar as cooperativas agrícolas como modos de vida que transcendam à mera busca de sobrevivência para significar um projeto de sociedade e de educação solidárias em construção.

O problema do trabalho também é um problema educacional porque todos nós aprendemos, o pouco que aprendemos, foi nesse ensino tradicional de competividade, exploração, dominação, até porque hoje muitas pessoas fazem pesquisa para uma proposta de educação do Movimento, voltada para a realidade do agricultor [...] Imaginem uma cooperativa de técnicos agrícolas, agrônomos, assistentes sociais e assim por diante... Poderia funcionar bem melhor porque tem mais acesso ao conhecimento e nós não tivemos; nós fomos excluídos da terra e do conhecimento. Então nós entendemos que este desnível, esta desconfiança em nós mesmos... O sistema faz nós ser desconfiante um do outro... (Agricultor E)

Contradições observadas tanto na construção de relações de trabalho, que sejam efetivamente cooperativas, solidárias e autogestionárias, quanto na formação escolar básica, que não contribui para o fortalecimento de tais relações, provocam questões à escola básica, que coloquei como foco de minhas preocupações. 


\section{Desafios da organização do trabalho cooperativo, no MST, à educação básica}

A pesquisa confirma o que os estudos sobre educação rural vêm mostrando, ou seja, que a escola oferecida aos filhos dos agricultores fundamenta-se em concepções/práticas de trabalho, de cultura, de relações sociais, de linguagem urbano-industriais. Mudanças profundas começam a ocorrer quando o MST contesta o modelo de sociedade baseado na concentração da terra e na exploração do trabalho, modelo este no qual se assentam as práticas e as concepções de educação rural. Ao mesmo tempo, este Movimento experimenta novas formas de organização do trabalho, baseadas na solidariedade, na cooperação e na autonomia, que sinalizam para a necessidade de revermos as práticas e as concepções que têm dado forma e conteúdo à escola básica e à formação de seus professores. As mudanças que conferem novos sentidos à propriedade da terra, ao trabalho dos agricultores e à educação por eles demandada não ocorrem sem conflitos, que, no caso da pesquisa, transparecem nas falas em que é possível captar o confronto entre concepções de mundo, de sociedade e de educação. Esse confronto, entretanto, não nos autoriza a colocar, em uma perspectiva linear e socialmente demarcada, os professores de um lado e os agricultores de outro. Portanto, nos conflitos que colocam em confronto as práticas/concepções de escola e de trabalho cooperativo, no caso da pesquisa o que é desenvolvido pelo MST, não há culpados nem vítimas; sobram questões materializadas em desafios para os sujeitos sociais que se enfrentam nesse embate: os agricultores assentados e os professores das escolas rurais.

Vinculados ao MST e as suas formas de organização e luta pela terra, os agricultores assentados vão criando soluções, repensando iniciativas, alguns abandonando o Movimento, outros retomando o trabalho individual. O mais importante, eles mesmos estão tentando, com autonomia, solidariedade e de forma cooperada, encontrar respostas aos desafios que a todo o momento lhes colocam a sobrevivência, a burocracia dos créditos, a impropriedade dos solos, a falta de água, a falta de preços mínimos e de mercados e a falta de formação escolar adequada que sustente as suas necessidades de planejar, preencher exigências burocráticas, fazer rodízio de cargos, permitindo que outros apreendam novas funções.

E para nós, professores formadores de outros professores, quais os desafios que colocam as novas modalidades de organização do trabalho, sejam elas informais, sejam elas populares e solidárias, sejam elas pseudocooperativas? Continuaremos teimando em preparar pessoas disciplinadas, com conhecimentos sobre algumas técnicas ligadas às profissões, quando escasseiam os empregos e até mesmo desaparecem muitos deles?

Por si só este já é um grande desafio que impõe repensar desde a formação de professores, o elenco de disciplinas e as atividades em que se assenta o currículo, a relação teoria/prática, a realidade na qual está inserida a escola, seja ela rural seja ela urbana, até as comunidades de pais e alunos destinatários do conhecimento escolar, porém eles próprios possuidores de saberes práticos nem sempre admitidos nos recintos freqüentados pelo conhecimento considerado "legítimo".

Experiências históricas de educação popular mostraram que a escola por si não modifica a realidade, mas a perseguição às pessoas que desenvolviam tais experiências mostraram também que as transformações não prescindem de formação escolar básica, orientada para projetos sociais emancipatórios. Se concordamos com essa premissa, penso, então, que precisamos estar atentos às mensagens de mudanças presentes nessas novas experiências de organização do trabalho, que apelam urgentemente por uma reflexão sobre a educação básica desenvolvida pelas escolas públicas, aquelas que recebem crianças e jovens oriundos das camadas subalternas onde se localizam os sujeitos criadores do trabalho cooperativo.

A escola tem estado associada aos valores do individualismo, da competição e da dependência, peculiares ao modo capitalista de produção que lhe define princípios e objetivos. Entretanto, é preciso considerar que as mudanças que ocorrem no mundo do traba- 
lho e na configuração do Estado, de um lado, e as formas cooperativas de trabalho associadas às organizações comunitárias e aos movimentos sociais populares, de outro, mostram uma sociedade em movimento, na qual as possibilidades de mudança não estão dadas mas vão sendo lentamente construídas. É preciso considerar, ainda, que a escola, nesse contexto de mudanças, não é uma entidade abstrata; ela reúne professores, pais e alunos numa mescla de interesses, culturas, conhecimentos que a pesquisa demonstrou ser impossível homogeneizar.

Assim, um dos maiores desafios que estão colocados para uma escola que tenha como perspectiva a cooperação, a solidariedade e a autonomia, me parece, concordando com Garcia (1997, p. 57), é o de construir uma proposta prático-teórica de pedagogia emancipatória, que "assuma a responsabilidade de democratizar a cultura universal, entendida como patrimônio da humanidade, [...] e democratizar a cultura nacional e popular", articulando, no mesmo processo, os saberes práticos do mundo do trabalho e da cultura locais, sejam urbanos sejam rurais, com os conhecimentos histórica e socialmente produzidos.

As contradições que aparecem nas falas dos sujeitos da pesquisa, sejam eles agricultores, sejam eles professores, mostram uma realidade rica e complexa na qual ainda há muitas questões a serem levantadas e analisadas. Por ora, é possível inferir, nos seus discursos, o conflito existente entre a prática/concepção de trabalho cooperativo agrícola, vivenciado nos assentamentos do MST, e o modelo de educação escolar básica. A partir daí, podemos formular algumas conclusões que nos desafiam a repensar a escola básica. São elas:

a) a educação rural, modelada pela cultura e pelo trabalho industrial urbano, tem sido instrumento de expropriação da terra e de expulsão de agricultores familiares;

b) a separação entre conhecimento e saber, com a valorização do primeiro em detrimento do segundo, legitima a anulação dos saberes da experiência dos agricultores; c) o currículo escolar, que tem como modelo o indivíduo competitivo, contrapõe-se ao trabalho cooperativo, que tem como valor básico a solidariedade;

d) a educação rural, comprometida com os interesses dos sujeitos sociais que vivem do trabalho da terra, pressupõe uma formação que articule a aquisição dos conhecimentos social e historicamente produzidos com os saberes produzidos pelo trabalho agrícola familiar, em especial o que se realiza de forma autogestionária, cooperada e solidária.

Além destas questões que nos desafiam a rever nossas práticas e concepções pedagógicas, haverá, por certo, outras que somente os protagonistas do trabalho cooperativo e da educação rural - agricultores assentados e professores rurais - poderão, em um processo coletivo de discussões, ao serem devolvidos os resultados da pesquisa, apontar. Não posso me antecipar a este processo, porém penso que as conclusões aqui enumeradas já significam enormes desafios à formação de professores do curso de Pedagogia, área na qual exerço minha prática como docente-pesquisadora.

MARLENE RIBEIRO, doutora em educação pela UFRGS, é professora titular na Faculdade de Educação dessa Universidade e coordenadora do Núcleo Trabalho, Movimentos Sociais e Educação. Publicou: Universidade brasileira "pós-moderna”: democratização x competência, Manaus, EDUA, 1999; Formação de professores e escola básica: perspectivas para a pedagogia, Educação $e$ Realidade, FACED/UFRGS, v. 25, n. 2, jul./dez. 2000, p. 179-202; Exclusão: problematização do conceito, Educação e Pesquisa, v. 25, n. 1, jan./jun. 1999, p. 35-49; Pedagogia da autonomia: uma análise da assistência técnica a agricultores assentados, Trabalho \& Educação, Belo Horizonte, NETE/FAE/UFMG, n. 8, jan./jul. 2001, p. 133-161. E-mail: maribe@adufrgs.ufrgs.br

\section{Referências Bibliográficas}

ANDERSON, Perry, (1995). Balanço do neoliberalismo. In: SADER, Emir, GENTILI, Pablo (orgs.). Pós-neoliberalismo: as políticas sociais e o estado democrático. Rio de Janeiro: Paz e Terra, p. 9-23. 
ARRUDA, Marcos, (1996). Globalização e sociedade civil. Repensando o cooperativismo no contexto da cidadania ativa. Rio de Janeiro: PACS.

AUED, Bernadete Wrublevski e outros, (1999). Educação para o (des)emprego. (Ou quando estar liberto da necessidade de um emprego é um tormento). Petrópolis: Vozes.

BOBBIO, Norberto e outros, (1995). Estado do bem-estar. Dicionário de política. $7^{\mathrm{a}}$ ed. Brasília: ed. UNB.

CALAZANS, Maria Julieta, (1993). Para compreender a educação do Estado no meio rural. Traços de uma trajetória. In: THERRIEN, Jacques, DAMASCENO, Maria. Educação e escola no campo. Campinas: Papirus, p. 15-42.

CALDART, Roseli Salete, (1997). Educação em movimento. Formação de educadores e educadoras do MST. Petrópolis: Vozes. (2000). Pedagogia do Movimento Sem Terra. Petrópolis: Vozes.

CAMINI, Isabela, (1998). O cotidiano pedagógico de professores e professoras em uma escola de assentamento do MST: Limites e desafios. Mestrado em Educação. Porto Alegre: PPGEDU/ UFRGS, $170 \mathrm{p}$.

CASTEL, Robert, (1998). As metamorfoses da questão social. Uma crônica do salário. Petrópolis: Vozes.

CORAGGIO, Jose Luis, (1999). Política social y economia del trabajo. Alternativas a la política neoliberal para la ciudad. Madrid. Miño y Dávila.

ENGUITA, Mariano, (1989). A face oculta da escola. Educação e trabalho no capitalismo. Porto Alegre: Artes Médicas.

FIORI, José Luis, (1998). Os moedeiros falsos. $4^{\mathrm{a}}$ ed. Petrópolis: Vozes.

FOUCAULT, Michel, (1984). Vigiar e punir. História da violência nas prisões. $3^{\mathrm{a}}$ ed. Petrópolis: Vozes.

GADOTTI, Moacir, GUTIÉRREZ, Francisco (orgs.), (1999). Educação comunitária e e conomia popular. $2^{\mathrm{a}}$ ed. São Paulo: Cortez.

GAIGER, Luiz Inácio, (1999). Significados e tendências da economia solidária. GT Economia Solidária. In: Sindicalismo e economia solidária: Reflexões sobre o projeto da CUT. São Paulo: CUT Nacional. dez., p. 29-42.

GARCIA, Regina Leite, (1997). A educação numa plataforma de economia solidária. Proposta, Rio de Janeiro, FASE, nº 74, p. $42-57$, set./nov.
GENTILI, Pablo, (1998). Educar para o desemprego: a desintegração da promessa integradora. In: FRIGOTTO, Gaudêncio. Educação e trabalho: Perspectivas de final de século. Petrópolis: Vozes, p. 76-99.

GOHN, Maria da Glória, (1997). Os sem-terra, Ongs e cidadania. São Paulo: Cortez. (1998). O novo associativismo e o terceiro Setor. Serviço Social e Sociedade, São Paulo, Cortez, nº 58, p. 09-23, nov. (2000). Mídia, terceiro setor e MST. Impactos sobre o futuro das cidades e do campo. Petrópolis: Vozes.

GRITTI, Silvana Maria, (2000). O papel da escola rural na penetração do capitalismo no campo. Mestrado em Desenvolvimento Social. Pelotas/RS. MDS/UCPel. 158 p.

INCRA/Ministério Extraordinário de Política Fundiária, (1996). Projeto Lumiar. Brasília: Gráfica do INCRA.

KAUTSKY, Karl, (1972). A questão agrária. Porto: Portucalense, vol. 1.

LENINE, Vladimir I., (1980). Sobre a cooperação. In: Obras Escolhidas. São Paulo: Alfa-Omega, vol. 3, p. 657-662.

LIMBERGER, Emiliano, (1996). Cooperativa. Empresa socializante. Porto Alegre: Imprensa Livre.

LUCAS, Rosa Elane Antória, (1999). Escola e sociedade, a questão agrária e a educação. Um estudo de caso em escolas que atendem crianças de assentamentos. Mestrado em Desenvolvimento Social. Pelotas/RS: MDS/UCPel, 223 p.

LUXEMBURGO, Rosa, (1986). Reforma social ou revolução? São Paulo: Global.

MANCE, Euclides André, (1999). A revolução das redes. Petrópolis: Vozes.

MARX, Karl, (1982). O Capital. Crítica da economia política. São Paulo: Difel, vols. I, II, III.

NUNES, Georgina Helena L., (1998). Um significado de escola a partir do cotidiano de crianças trabalhadoras da zona rural. Mestrado em Educação. Pelotas/RS: FAE/UFPel, 172 p.

OLIVEIRA, Francisco de, (1998). Os direitos do antivalor. A economia política da hegemonia imperfeita. Petrópolis: Vozes.

PARO, Vitor Henrique, (1999). Parem de preparar para o trabalho!!! Reflexões acerca dos efeitos do neoliberalismo sobre a gestão e o papel da escola básica. In: FERRETTI, Celso e ou- 
Trabalho cooperativo no MST e ensino fundamental rural

tros. Trabalho, formação e currículo. Para onde vai a escola? São Paulo: Xamã, p. 101-120.

RAZETO, Luis, (1999). Economia da solidariedade e organização popular. In: GADOTTI, Moacir, GUTIÉRREZ, Francisco (orgs.). Educação comunitária e economia popular. $2^{\mathrm{a}}$ ed. São Paulo: Cortez, p. 34-58.

RECH, Daniel, (1995). Cooperativas. Uma alternativa de organização popular. Rio de janeiro: FASE.

RIBEIRO, Marlene, (1997). Trajetória da educação liberal: alguns traçados. Cadernos de Educação, Pelotas/RS: FAE/UFPel, $n^{\circ} 9$, p. $155-184$, ago./dez.

(2000a). Educação básica do campo: um desafio aos trabalhadores da terra. Palestra $n^{\circ} 08$, publicada por http:// www.bnaf.org.br, abril, 7 p.

(2000b). Relatório final de avaliação do Projeto Lumiar. Porto Alegre: INCRA, COCEARGS, CAPA, UFRGS, fev., 25 p.

(2000c). Pedagogia da autonomia: uma análise da assistência técnico-pedagógica a agricultores assentados. Trabalho inédito. 24 p.

RIFKIN, Jeremy, (1995). O fim dos empregos. São Paulo: Makron Books.

SECCO, Lincoln, (1998). Gramsci: hegemonia e pós-fordismo. In: Universidade e Sociedade, São Paulo, ANDES/SN, n 16, $\mathrm{p}$. 82-96, jun.

SCHNEIDER, José Odelso, (1999). Democracia, participação e autonomia cooperativa. $2^{\mathrm{a}}$ ed. São Leopoldo: UNISINOS.

SINGER, Paul, (1997). Economia solidária: geração de renda e alternativa ao liberalismo. Proposta, Rio de Janeiro, FASE, $\mathrm{n}^{\circ}$ 72, p. 06-13, mar./maio.
(1998). Globalização e desemprego: diagnóstico e alternativas. São Paulo: Contexto.

(1999a). Cooperativismo e Sindicatos no Brasil. GT Economia Solidária. In: Sindicalismo e economia solidária: reflexões sobre o projeto da CUT. São Paulo: CUT Nacional, dez., p. 23-28.

(1999b). Possibilidades da economia solidária no Brasil. GT Economia Solidária. In: Sindicalismo e economia solidária: reflexões sobre o projeto da CUT. São Paulo: CUT Nacional, dez., p. 51-58.

(2000). Economia solidária: um modo de produção e distribuição. In: SINGER, Paul, SOUZA, André Ricardo de, (orgs.). A economia solidária no Brasil. A autogestão como resposta ao desemprego. São Paulo: Contexto.

SINGER, Paul, SOUZA, André Ricardo de (orgs.), (2000). A economia solidária no Brasil. A autogestão como resposta ao desemprego. São Paulo: Contexto.

TIRIBA, Lia Vargas, (1998). Economia popular e produção de uma nova cultura do trabalho: contradições e desafios frente à crise do trabalho assalariado. In: FRIGOTTO, Gaudêncio, (org.). Educação e crise do trabalho: perspectivas de final de século. Petrópolis: Vozes, p. 189-217.

TODESCHINI, Remígio, MAGALHÃES, Reginaldo, (1999). A CUT e a Economia Solidária. GT Economia Solidária. In: Sindicalismo e economia solidária: reflexões sobre o projeto da CUT. São Paulo: CUT Nacional, dez., p. 11-22.

THOMPSON, Edward P., (1984). Tradición, revuelta y consciencia de clase. Estudios sobre la crise de la sociedad preindustrial. $2^{\text {a }}$ ed. Barcelona: Ed. Crítica Grijalbo. 


\section{Resumos/Abstracts}

François Dubet

\section{As desigualdades multiplicadas}

Nossas sociedades são dominadas por uma contradição fundamental: como sociedades democráticas, afirmam a igualdade por essência de todos os sujeitos. Como sociedades capitalistas, não param de construir mercados que hierarquizam as competências e os méritos. Tal contradição parece cada vez menos superada. Como conciliar a igualdade de todos e o mérito de cada um? Presenciamos o surgimento de movimentos sociais que reivindicam o reconhecimento dos indivíduos - independentemente do seu mérito - e uma igualdade de princípio que se converte facilmente em culpa, em desprezo e em violência. De fato, sem renunciar à busca da igualdade, a dupla natureza de nossas sociedades exige que constituamos uma política de reconhecimento do sujeito.

\section{Multiplying the inequalities}

Our societies are dominated by a fundamental contradiction: as democratic societies, they affirm the essential equality of all subjects but as capitalist societies they do not cease to construct markets which establish hierarchies of competence and merit. This contradiction appears to increase rather than diminish. How is it possible to reconcile equality for all and individual merit? Social movements are created which demand the recognition of individuals - independent of merit - and a principle of equality that is easily converted into blame, contempt and violence. Without abandoning the search for equality, the double nature of our societies requires that we establish a policy for the recognition of the subject.

\section{Les inégalités multipliées}

Nos sociétés sont dominées par une contradiction fondamentale: sociétés démocratiques, elles affirment l'égalité par essence de tous les sujets; sociétés capitalistes, elles ne cessent de construire des marchés Qui hérarchisent les compétences et les mérites. Cette contradiction semble de moins en moins maïtrisée. Comment concilier l'égalité de tous et le mérite de chacun? On voit se former des mouvements sociaux qui en appellent à la reconnnaissance des individus - indépendament de leur mérite - et à une égalité de principe qui se retourne aisément en culpabilité, en mépris et en violence. En fait, tout en ne renonçant pas à la recherche de l'égalité, la double nature de nos sociétés exige que se forme une politique de reconnaissance du sujet.
Marlene Ribeiro

Trabalho cooperativo no MST e ensino fundamental rural: desafios à educação básica

O objetivo deste artigo é averiguar que desafios o trabalho cooperativo, desenvolvido por agricultores assentados, coloca à escola básica. A metodologia articula uma revisão bibliográfica sobre economia solidária com a pesquisa-ação, feita em assentamentos de reforma agrária e escolas rurais, no município de Piratini/RS, focalizando a relação entre o trabalho cooperativo e a educação escolar. As falas dos sujeitos evidenciam o conflito entre a formação exigida pelo trabalho cooperativo agrícola e o modelo de escola básica em que se fundamenta a educação rural.

Co-operative work: challenges for the primary school

The purpose of this paper is to identify those challenges which cooperative work, developed by 'settled' farmers, raise for the primary school. The methodology involves a literature review about economic solidarity and actionresearch carried out in settlements established by the Land Reform and in rural schools in the municipality of Piratini/RS. The research focuses on the relation between co-operative 
work and school education. The discourse of the subjects of the research reveals the conflict between the formation required for cooperative agricultural work and the model of basic education on which rural education is based.

\section{Isabel Lelis}

Profissão docente: uma rede de histórias

Este artigo tem o objetivo de analisar a identidade social do magistério das séries iniciais do ensino fundamental, forjada em processos de socialização familiar, escolar e profissional. Através do recurso às histórias de vida de treze professoras, foi possível perceber que muitos são os significados atribuídos ao trabalho docente. Recorrendo ao aporte da sociologia de Pierre Bourdieu, o trabalho permitiu compreender a constituição de habitus para a docência, as estratégias desenvolvidas pelas professoras para a conquista de títulos escolares, os modos de entrada na profissão, o peso da formação prévia e continuada nas formas como as professoras vivem e representam o trabalho que realizam. Considerando que a representação social do magistério, no contexto de uma escola de massa, foi alterada, o estudo acabou por problematizar imagens de passividade, negligência e incompetência que têm sido atribuídas às professoras pelas burocracias educacionais e agências governamentais.

The teaching profession: a webs of stories

This article proposes to analyse the social identity of teachers in the first series of primary education, forged through processes of professional, school and family socialization. Using the life stories of thirteen women teachers, the article discusses the significance attributed to the teaching profession. Taking Pierre Bourdieu's sociology as reference, the study explores the constitution of the habitus in teachers, the strategies they use to achieve academic qualifications, admission to the profession and the weight of initial and continued training in the way teachers experience and represent their work. This study challenges the images of passivity, negligence and technical incompetence that are attributed to teachers by educational authorities and governamental agencies, by recognizing that, at a time in which a massification of school is occuring, the social representation of teaching has been modified.

\section{Claudio Suasnábar}

Resistência, mudança e adaptação nas universidades argentinas: Problemas conceptuais e tendências emergentes no governo e na gestão acadêmica

$\mathrm{O}$ artigo propõe-se a fazer uma contribuição ao debate teóricometodológico dos referenciais conceptuais mais adequados para o estudo dos problemas do governo e da gestão universitária na Argentina.

Este trabalho também constitui uma primeira posta à prova do instrumental apresentado. São analisadas as tensões que geram as políticas estatais na gestão acadêmica. Considerase que a emergência de uma dupla linha de gestão e condução na institucionalização de novos atores nas universidades argentinas configuram os dois fenômenos que disputam o papel historicamente atribuído aos conselhos acadêmicos. Essas tensões, que hoje percorrem os processos de mudança institucional, expressam o conflito entre as novas formas de gestão e o modelo de co-governo que instaurou a Reforma Universitária de 1918.
Resistance, change and adaptation in argentine universities: concept problems and tendencies emerging from academic government and management

This article aims to contribute to the theoretical and methodological debate on the most suitable conceptual frameworks for studying the problems of government and management in Argentinian universities. The paper also constitutes a first test of the instruments presented therein. Tensions generated by state policies on academic management are also analysed. The article considers that the emergence of a double line of manegement and condut of the institution of new actors in Argentinian universities constitute the two phenomena which dispute the role historically attributed to academic councils. These tensions, which underlie processes of institutional change the, are the expression of conflicts between new forms of management and the model of cogovernment that established the Argentinian University Reform of 1918.

Afrânio Mendes Catani, Denice Bárbara Catani e Gilson R. de M. Pereira

As apropriações da obra de Pierre Bourdieu no campo educacional brasileiro, através de periódicos da área

A partir de pesquisa realizada em 20 periódicos especializados em educação, editados entre 1971 e 2000, são analisadas as formas de apropriação da obra de Pierre Bourdieu no campo educacional brasileiro. O conjunto dos 355 artigos publicados nesses periódicos que fazem referências ao sociólogo constitui o corpus básico para a análise das peculiaridades das interpretações brasileiras do autor. 